\title{
Aerobics in the System of Educational Organizations Physical Education
}

\author{
Mikhailova E.I. \\ Moscow State Pedagogical University \\ Moscow, Russia \\ elvira.mikhailova@gmail.com
}

\author{
Mikhailov N.G. \\ Moscow State Pedagogical University \\ Moscow, Russia \\ ivda@mail.ru
}

\author{
Derevleva E.B. \\ Moscow State Pedagogical University \\ Moscow, Russia \\ ederevleva@mail.ru
}

\begin{abstract}
The reforms of education in Russia cause changes in the system of educational organizations physical education. The authors show the possibility to use aerobics means and methods for many-sided personality formation within a wide age range from pre-school children till senior schoolchildren. The article presents the results of long-term research works concerning aerobics influence on physical readiness of pre-school children and general education students. The article shows the opportunity to use different kinds of aerobics for improving health state of children and youth.
\end{abstract}

Keywords—physical upbringing; general education; aerobics; physical readiness; school children's health

\section{INTRODUCTION}

Nowadays the process of educational system reformation in the Russian Federation is very active. It is connected with the changes in its content [1] and is realized by means of personal, cross-curricular and subject results formation. They form the orientation of the developing personality towards a harmonious development [7].

Physical upbringing, as the part of the education and upbringing process, also changes its content in the part of motor activity kinds, physical upbringing means. They are used during physical culture lessons at educational organizations $[5,8,9]$. The choice of motor activity kind for physical upbringing formation among children and youth is still very urgent in the system of general education. Aerobics helps to solve the whole complex of physical training problems, health improvement among children and youth $[2$, $3,6,7,10]$.

\section{MATERIALS AND METHODS}

The article presents the results of long-term research works at Moscow Municipal Pedagogical University.

The first pedagogical experiment (PE1) was held at a preschool educational establishment. Aerobics lessons were held with 5-6 year-old children in the system of additional education. Three complexes of aerobics with accented development of coordination, flexibility, strength and endurance were created for children. The experiment was held during 9 months and provided lessons two times a week (30 minutes each). 24 children took part in the experiment. 12 people were in the experimental group (EG) and 12 people were in the control (CG) group. CG trained according to the program of general physical training.

The second pedagogical experiment (PE2) included aerobics lessons for the $1^{\text {st }}$ form pupils. They trained according to "Aerobics alphabet" Program. The program volume was 102 hours. Aerobic exercises took 34 hours and formed the content of the third physical culture lesson. The content of the program provided the main elements of aerobics mastering. They then were united into combinations. During the period of program mastering first form pupils mastered the whole spectrum of elements, necessary for competitive aerobics program creation for children of this age. 18 (EG) and 15 (CG) first form girls took part in the second experiment.

The third pedagogical experiment (PE3) was realized at physical culture lessons with 12-13 year-old children. For these children innovative approaches were used in order to project physical culture lessons content. They provided fitness-aerobics exercises fulfillment. The lessons with the children from EG $(n=15)$ and CG $(n=15)$ were held three times a week. 
At each lesson EG studied one eight, after studying one combination one more eight was added, which then were repeated altogether. After mastering four eights all exercises were fulfilled with music and without demonstration to teachers - to train awareness.

The $4^{\text {th }}$ pedagogical experiment $(\mathrm{PE} 4)$ was held at senior school. In the experimental group $(n=12)$ lessons included aerobic exercises with dumbbells ( 1 and $2 \mathrm{~kg}$ ) and also armpumping exercises in prone position. CG included 12 schoolgirls (the $10^{\text {th }}$ form). The experiment lasted one academic year.

In PE2-PE4 in the CG children trained according to a complex program of physical upbringing by V.I. Lyakh [4].

\section{RESULTS}

As a result of PE 1 the respondents of the EG achieved valid increase of strength indices $(p<0,01)$. The number of shoulder dips increased from $1 \pm 1$ till $4 \pm 3$ times. They were higher than the indices in the $\mathrm{CG}$ during the repeated testing (TABLE I).

TABLE I. THE RESULTS OF PHYSICAL READINESS LEVEL TESTING IN PRE-SCHOOL CHILDREN (EG AND CG)

\begin{tabular}{|c|c|c|c|c|c|}
\hline \multirow{2}{*}{\multicolumn{2}{|c|}{ Indices }} & \multicolumn{2}{|c|}{ Group } & \multirow[t]{2}{*}{$\begin{array}{c}\text { Compari } \\
\text { son, in } \\
\text { case } \alpha= \\
0.05\end{array}$} & \multirow[t]{2}{*}{$\begin{array}{l}\text { Validity } \\
\text { of } \\
\text { differenc } \\
\text { es, } P\end{array}$} \\
\hline & & CG & EG & & \\
\hline \multirow{2}{*}{$\begin{array}{c}\text { Shoulder dip, } \\
\text { quantity }\end{array}$} & $I^{*}$ & $1 \pm 0,8$ & $1 \pm 1$ & 0,14 & $>0,05$ \\
\hline & $\mathrm{f}$ & $1 \pm 0,6$ & $4 \pm 3$ & 2,79 & $<0,01$ \\
\hline \multirow{2}{*}{$\begin{array}{l}\text { Lateral split, } \\
\mathrm{cm}\end{array}$} & i & $14,6 \pm 5,0$ & $12,9 \pm 1,8$ & 1,01 & $>0,05$ \\
\hline & $\mathrm{f}$ & $14,4 \pm 4.5$ & $9,6 \pm 5,9$ & 2,44 & $<0,05$ \\
\hline \multirow{2}{*}{$\begin{array}{c}\text { Romberg's } \\
\text { test, s }\end{array}$} & $\mathrm{i}$ & $6,4 \pm 3,9$ & $5,7 \pm 3,9$ & 0,56 & $>0,05$ \\
\hline & $f$ & $8,8 \pm 2,2$ & $11,6 \pm 2,5$ & 3,02 & $<0,01$ \\
\hline \multirow{2}{*}{$\begin{array}{c}\text { Connective- } \\
\text { combination, } \\
\text { amount of } \\
\text { mistakes }\end{array}$} & $\mathrm{i}$ & $2,4 \pm 2,7$ & $2,7 \pm 1,3$ & 0,23 & $>0,05$ \\
\hline & $\mathrm{f}$ & $1,8 \pm 1,1$ & $1,1 \pm 1,0$ & 1,48 & $>0,05$ \\
\hline
\end{tabular}

Flexibility indices also improved in "lateral split" exercise (table 1).

PE2 results show more considerable improvement in the main physical qualities development in EG girls in comparison with their CG coevals. Flexibility and power endurance indices in EG girls turned out to be validly higher $(\mathrm{P}<0,001$, TABLE II $)$

PE3 results prove positive influence of fitness-aerobics lessons on quickness and coordinating abilities development. It is proved by shuttle run $3 \times 10 \mathrm{~m}$ results improvement. It decreased from 9.8 $\pm 0,2$ till 9,4 $\pm 0,2$ seconds in $\mathrm{EG}(\mathrm{P}<0,001)$. There is also speed-power abilities improvement, proved by the length of the standing jump increase in EG from 145 $\pm 6,3$ till $156 \pm 7,3 \mathrm{~cm}(\mathrm{P}<0.001)$. In the $\mathrm{CG}$ within the same period, there was no valid increase of these indices (TABLE III).

TABLE II. THE RESULTS OF THE FINAL TEST IN THE FIRST FORM GIRLS (CG AND EG)

\begin{tabular}{|c|c|c|c|c|}
\hline \multirow[t]{2}{*}{ Test } & \multicolumn{2}{|c|}{ Results } & \multirow[b]{2}{*}{$\begin{array}{l}\text { Student t-test } \\
\text { value }\end{array}$} & \multirow{2}{*}{$\begin{array}{c}\text { Validity } \\
\text { level, } \\
\text { P }\end{array}$} \\
\hline & $\begin{array}{c}\begin{array}{c}C G \\
(\mathrm{n}= \\
15)\end{array} \\
\end{array}$ & $\begin{array}{c}\begin{array}{c}\text { EG } \\
(\mathrm{n}=\end{array} \\
18)\end{array}$ & & \\
\hline $\begin{array}{l}500 \text { meters running, } \\
\text { min }\end{array}$ & $3,33 \pm 0,2$ & $3,02 \pm 0,4$ & 2,88 & $\mathrm{P}<0,01$ \\
\hline $\begin{array}{l}\text { Forward bend sitting, } \\
\mathrm{cm}\end{array}$ & $5,0 \pm 0,7$ & $13,0 \pm 0,8$ & 30.76 & $\mathrm{P}<0,001$ \\
\hline Front hang, seconds & $4,9 \pm 0,3$ & $8,0 \pm 0,5$ & 22,14 & $\mathrm{P}<0,001$ \\
\hline $\begin{array}{l}30 \text { meters running, } \\
\text { seconds }\end{array}$ & $6,8 \pm 1,6$ & $6,3 \pm 0,3$ & 1,35 & $P>0,05$ \\
\hline $\begin{array}{l}\text { Shuttle run } \\
3 \times 10 \text { meters, seconds }\end{array}$ & $\begin{array}{c}11,3 \pm 0 \\
9\end{array}$ & $\begin{array}{l}10,7 \pm 0 \\
5\end{array}$ & 2,31 & $\mathrm{P}<0,05$ \\
\hline
\end{tabular}

TABLE III. DYNAMICS OF TEST RESULTS CHANGES DURING THE PEDAGOGICAL EXPERIMENT

\begin{tabular}{|c|l|l|l|c|c|}
\hline \multirow{2}{*}{ Indices } & \multicolumn{2}{|c|}{ Group } & Comparison, in & $\begin{array}{c}\text { Validity of } \\
\text { case } \alpha=0.05\end{array}$ \\
\cline { 2 - 6 } & \multicolumn{2}{|c|}{ CG } & EG & & \\
\hline $\begin{array}{c}30 \text { meters } \\
\text { running, } \\
\text { seconds }\end{array}$ & i & $6,4 \pm 0,2$ & $6,3 \pm 0,2$ & 1,4 & $>0,05$ \\
\cline { 2 - 6 } & f & $6,3 \pm 0,2$ & $5,9 \pm 0,3$ & 7,75 & $<0,001$ \\
\hline $\begin{array}{c}\text { Standing } \\
\text { long- jump, } \\
\text { cm }\end{array}$ & i & $140 \pm 5,5$ & $145 \pm 6,3$ & 2,01 & $>0,05$ \\
\cline { 2 - 6 } & f & $145 \pm 6,0$ & $156 \pm 7,3$ & 3,8 & $<0,01$ \\
\hline $\begin{array}{c}\text { Shuttle run } \\
3 \times 10 m, \\
\text { seconds }\end{array}$ & i & $9,9 \pm 0,2$ & $9,8 \pm 0,2$ & 0,2 & $>0,05$ \\
\cline { 2 - 6 } & f & $9,8 \pm 0,2$ & $9,4 \pm 0,2$ & 5,6 & $<0,001$ \\
\hline
\end{tabular}

TABLE IV. RESULTS OF TEST IN THE SENIOR PUPILS (CG AND EG)

\begin{tabular}{|c|c|c|c|c|c|}
\hline \multirow[b]{2}{*}{ Tests } & & \multicolumn{2}{|c|}{ Groups } & \multirow{2}{*}{$\begin{array}{c}\text { Student } \\
\text { t-test }\end{array}$} & \multirow{2}{*}{$\begin{array}{c}\text { Significance } \\
\text { level, P }\end{array}$} \\
\hline & & $\begin{array}{c}\mathrm{CG} \\
(\mathrm{n}=15)\end{array}$ & $\begin{array}{c}\text { EG } \\
(n=15)\end{array}$ & & \\
\hline \multirow{2}{*}{$\begin{array}{l}\text { Sit-ups, } \\
\text { quantity }\end{array}$} & Before & $22 \pm 6$ & $23 \pm 5$ & 0,54 & $>0,05$ \\
\hline & After & $23 \pm 6$ & $27 \pm 5$ & 2,16 & $<0,05$ \\
\hline \multirow{2}{*}{$\begin{array}{l}\text { Dip-up, } \\
\text { quantity }\end{array}$} & Before & $10 \pm 5$ & $11 \pm 4$ & 0 & $>0,05$ \\
\hline & After & $12 \pm 5$ & $15 \pm 4$ & 1.81 & $>0,05$ \\
\hline \multirow{2}{*}{$\begin{array}{l}\text { Forward } \\
\text { bend } \\
\text { sitting legs } \\
\text { together, } \\
\mathrm{cm}\end{array}$} & Before & $0,7 \pm 6,0$ & $0,7 \pm 6,2$ & 0 & $>0,05$ \\
\hline & After & $1,7 \pm 5,0$ & $4,8 \pm 3,2$ & 2,15 & $<0,05$ \\
\hline \multirow{2}{*}{$\begin{array}{l}\text { Hopping } \\
\text { over the } \\
\text { skipping } \\
\text { rope, } \\
\text { quantity }\end{array}$} & Before & $99 \pm 5$ & $100 \pm 5$ & 0,55 & $>0,05$ \\
\hline & After & $101 \pm 6$ & $113 \pm 8$ & 4,68 & $<0,01$ \\
\hline
\end{tabular}


The results of the comparative analysis prove that the choice of exercises from fitness-aerobics in accordance with the offered methodology had effective influence on the process of physical qualities development among EG children.

PE4 results prove that senior EG pupils had indices increase. They characterize power qualities, endurance and flexibility. They turned out to be validly higher in comparison with the results in the $\mathrm{CG}$ and also they had coordinating abilities improvement. They are characterized by time increase of balance preservation (TABLE IV).

Using different kinds of aerobic exercises goes together with a purposeful physical readiness indices improvement and pupils' health improvement during the whole period of studying at school.

\section{CONCLUSION}

Modern development of aerobics and its kinds helps to solve the problems of children upbringing and education. They study in the system of general education. Special importance aerobic exercises have for physical training of the oncoming generation, motivation for physical-health improving and physical-sports activity increase. The effectiveness of physical upbringing process is conditioned by the content of aerobic exercises. They are used during different forms of physical culture lessons organization.

\section{References}

[1] Barannikov K.A., Vachkova S.V., Demidova M.Yu., Remorenko I.M., Reshetnikova O.A. About the content of education regulation at a modern stage of educational system transformation in the Russian Federation. Journal of Education. 2016, vol. 14, pp. 69-80.

[2] Kryuchek S.S. Aerobics. Content and methodology of health improving lessons organization. Manual - Moscow: Tera-sport, Olimpiya press. 2001, 64.

[3] Lisitskaya T.S., Sidneva L.V. Aerobics: In 2 volumes. Volume1 Theory and methodology. Moscow: Aerobics Federation of Russia. 2002, 232.

[4] Lyakh V.I. Complex program of physical upbringing. Moscow: enlightenment. 2009, 134.

[5] Matveev L.P. Theory and methodology of physical culture. The $3^{\text {rd }}$ edition, transformed and added. Moscow: Physical culture and Sport, SportAkademPress. 2008, 544.

[6] Mikhailova E.I., Mikhailov N.G. Aerobics at school: methodical manual for physical culture teacher. Moscow: Soviet sport. 2014, 124.

[7] Mikhailova E.I., Mikhailov N.G. Aerobics: textbook for physical culture faculties. Moscow: GBOU VPO MGPU. 2015, 178.

[8] Stradze A.E. Conceptual basis of physical upbringing transformation at a modern stage (the introduction of the editor-in-chief: in the materials of the IX All-Russian scientific-practical conference "Innovative technologies in sport and physical upbringing of the oncoming generation". Moscow: MGPU. 2019, pp. 23-28.

[9] Strategy of physical culture and sport development in the Russian Federation during the period till 2020. The collection of the official documents and materials of the Ministry of sport, tourism and youth politics of the Russian Federation. 2009, vol. 10, pp. 13-32.

[10] Walseth K., Aartun I., Engelsrud G. Girls' bodily activities in physical education How current fitness and sport discourses influence girls' identity construction. Journal Sport, Education and Society. 2017, vol. 22(4), pp. 442-459.

[11] Kasatkina N.A., Panova E.O., Guryanova S.A. Tactical Thinking as a factor of technical readiness level increase in sports aerobics. The Russian 